In the comments which I added to the views of these eminent observers, wherein I mentioned those circumstances that seemed to me to tend in the direction of their support, I was, of course, unable to include, as I would if possible have done, a statement of the opinions of such noted authorities as Dr. Steube and Herr von Siebold, the results of whose investigations have so recently been given to the press, and which are cited in the article that elicits this letter.

Marburg, Germany, February 8

J. J. REIN

\section{Hovering of Birds}

I REGRET that I did not notice until to-day that Mr. Airy, in his letter published in NATURE, vol. xxvii. p. 294, specially referred to "hovering with perfectly motionless wings" as being that for which an upward slant of wind is, as be believes, absolutely requisite to enable the bird to do so.

Is the term " hovering" applicable to the exam: les given by Mr. Airy of gulls and hawks floating as it were $\mathrm{v}$ ith motionless wing elong hillsides and cliffs?

I have always associated "hovering" with the flapping or fluttering of the wings, as is invariably noticed when terns or hawks are looking for their prey either over land or water.

February 10 J. R.

\section{Intelligence in Animals}

IN his letter in NATURE, vol, xxvii. p. 337, Mr. J. Birmingham does not mention what hind of bear it is that throws down pieces of rock "in order to ca"ch the bareins," as told by the Kamtschadales ; but the Eskimos have a somewhat similar story of the white bear, when attacking the walrus, the largest of which, with their formidable tusks, Bruin generally avoids.

The circumstance was told me by an eye witness, a very truthful and honest Eskimo of Repulse Bay. He said : "I and two or three other Innuit were attempting to approach some walrus in winter, lying on the ice close to the water, kept open by the strong current, in Fox's Channel. As we were getting near we saw that a large white bear was before us. He had reached in the most stealthy manner a high ridge of ice, immediately above where the walrus were lying; he then seized a mass of ice $^{1}$ in his paws, reared himself on his bind legs, and tbrew the ice with great force on the head of a half-grown walrus, and then sprang doun upon it."

The Eskimos then ran up, speared the bear, and found the walrus all but dead, thus securing both animals. I should add that the bear threw the ice as if he was "left-pawed."

Kensington, February Io

J. RAE

WHILE spending the late winter months at Paignton, in Devon, I frequently watched, through a telescope, shore birds of varicus kinds stalking game on the low tide sands. These abound with sand-eels, which lie, perfectly concealed, about an inch below the surface, and are caught in the following way ty the gulls.

Standing close to the water's edge, the birds tread the wet sand into soft puddles by rapid alternate movements of their feet, and when a sand-eel, thus disturbed, makes a dart for the sea, he is instantly taken by a skilful but leisurely-looking snap of the beak.

Sand.eels bury themselves withont leaving any marks on wet sand, and the gulls were always seen steadily and tentatively beating over the ground in the way I bave described. They took, each, a fish a minute, perhaps, and impressed me with the idea that some thoughtful ancestral gull had ceserved well of his race for the invention of such an easy logical vay of picking up a living.

Holmwood, Putney Hill, February 7

\section{The Sea-Serpent}

ON reading the letter of $W$. Steadman Aldis in NATURE (vol: xxvii. p. 338) yesterday, I was reminded by a person present that some years ago, when in Orkney, I pointed out an appearance that most people unaccustomed to witne:s it might have taken for a great sea-monster. This was no hing more or less than some hundreds of cormorants or "scarps"

x It may be questioned how the bear could find a lump of detached ice. The strong current mentioned is constantly breaking up the ice into small pieces. flying in a continuous line close to the water, the deception being increased by the resemblance of a head caused by several "scarps" in a cluster heading the column, and by the "lumpy" seas of a swift tideway frequently intervening and hiding for an instant part of the black lines, causing the observer to-not unnaturally-imagine that the portions so hidden had gone under water. The speed of the cormorant on the wing may be fairly estimated at thirty miles an hour or more.

Kensington, February 10

\section{The "Zoological Record"}

I SHOULD like to point out a slight error in the last impression of NATURE (p. 3II). In your notice of the Zoological Record, I $88 \mathrm{I}$, it is stated that no separate paper seems to have appeared in $188 \mathrm{I}$ exclusively devoted to the group Octactinia. I should mention that Prof. Nicholson's book on "Monticulipora," his paper on the skeletun of "Tubipora," and Mr. Wilson's paper on the development of "Renilla," all appeared in $188 \mathrm{r}$, and were duly recorded by me. SyDNEY J. Hickson

Anatomical Department, Museum, Oxford, February 5

\section{SIEVE-TUBES}

CAREFUL examination by E. Russow ( $\mathrm{Ann}$. Sci. Nat. xiv. I882, Nos. 3 and 4 ) of the structure and development of sieve-tubes leads him to the following general conclusions.

In all vascular plants examined, the sieve-tubes exhibit a remarkable agreement in structure, always expressed by the presence of callus. The sieve-punctation appears to be wanting in Isoetes, and possibly also in the Marattiaceæ. It is not, when present, confined to the sieve-tubes, bit occurs also in the parenchyma of the secondary liter. It is often difficult to decide whether these punctations are actually perforated; but this is clearly the case wherever the sieve is traversed by callose cushions or striæ, or by connecting filaments ; the presence of callus is not of itself sufficient to indicate perforation, for its formation certainly precedes the perforation of the membrane. In conifers the punctations between the sievetubes and the cells of the medullary rays are provided with callose cushions only on the side of the sieve-tubes, and the punctations remain closed.

The development, accumulation, and final disappearance of the callus indicate that it is not a product of transformation of the cellulose, but that it is separated from the contents of the sieve-tubes; its accumulation round the perforations is proportionate to the freedom and duration of the intercommunication that takes place through them; this communication probably continues as long as the striæ of the callus remain clearly developed, and ceases when these disappear, close up the sieve-pores, and end the function of the sieve-tubes.

In gymnosperms and vascular cryptogams, mucilaginous filaments are never to be seen traversing the callose cushions, although there is always a certain ainount of communication between the elements of the sieve-tubes. The special function of the sieve-tubes is probably always maintained wherever striæ cross the callose cushions. The large number of plants in which the sieves are traversed, both in summer and winter, by mucilaginous filaments, and the large number in which no such filaments are at any time observable, contradicts the idea that the function of the callus is to close the sieve-pores during the dormant season.

Much less callus is deposited in the sieve-tubes of closed fibrovascular bundles, especially in permanent organs, than in those of open bundles which increase in thickness from the activity of their cambium. This difference corresponds to a difference in the nature of the contents, and in the duration of the activity of the sievetubes. While in gymnosperms and dicotyledons the active period of the sieve-tubes rarely exceeds two years, in monocotyledons and vascular cryptogams it lasts as long as the organ itself. A stem of Alsophila, at least 